Artur WOŹNY ${ }^{1}$

\title{
AGENDY INFORMACYJNO-PROPAGANDOWE POLSKIEGO PAŃSTWA PODZIEMNEGO
}

\begin{abstract}
Artykuł traktuje o strukturach informacyjnych, prasowych w ramach formacji wojskowych oraz cywilnych Polskiego Państwa Podziemnego. Ukazano genezę, rolę i cele tajnej działalności propagandowej. Zaprezentowano również konkretne dokonania organizacyjne w tym zakresie ze strony Armii Krajowej, a także Delegatury Rządu na Kraj.
\end{abstract}

Slowa kluczowe: Polskie Państwo Podziemne, Armia Krajowa.

\section{PODSTAWY ORGANIZACYJNE KONSPIRACYJNEJ PROPAGANDY}

Rola działań propagandowych w warunkach wojennych jest oczywista i znana od dawna. Jej znaczenie jeszcze wyraźniej wzrosło od XIX w., w okresie kolejnych zmagań o charakterze totalnym, a potem konfliktów światowych ${ }^{2}$. Akcje propagandowe nabierały również specjalnej rangi $\mathrm{w}$ ramach niepodległościowych dążeń narodów podbitych, uciemiężonych. Wszystkie działania mające na celu odbudowę suwerennego bytu były zawsze wspierane, a nawet inspirowane niezależnym, wolnym słowem ${ }^{3}$. Nie rozwijając wątku genezy i samych dziejów wydawnictw konspiracyjnych, przypomnijmy, że swego rodzaju wykładnię zarówno roli, jak i zasad funkcjonowania ,bibuły”, czyli druków podziemnych - nielegalnych - przedstawił w 1903 r. Józef Piłsudski ${ }^{4}$. Późniejszy marszałek pisał: „Słowo drukowane w obecnym społeczeństwie jest uznaną powszechnie potęga". Niestety, po dwudziestu latach od ponownego zaistnienia niepodległej Polski dla kilku kolejnych pokoleń wydawnictwa tajne, bezdebitowe znowu musiały się stać niezwykle ważnym orężem $\mathrm{w}$ walce $\mathrm{z}$ okupantami i systemami totalitarnymi.

Znawca tematu Grzegorz Mazur zauważył, że to właśnie II wojna światowa była tă, podczas której na skalę wyjątkową zastosowano metody wojny psychologicznej. „Po oręż ten sięgnęły wszystkie biorące w niej udział państwa. Chodziło zarówno o mobilizację

\footnotetext{
${ }^{1}$ Dr Artur Woźny, Zakład Nauk Humanistycznych, Wydział Zarządzania, Politechnika Rzeszowska.

${ }^{2}$ Podczas powstania styczniowego w latach 1863-1864 ukazywało się około 70 tytułów różnych czasopism, w tym część w kilkutysięcznych nakładach. Zob. S. Kieniewicz, Powstanie styczniowe, Warszawa 1972.

${ }_{3}^{3}$ Zob. B. Wyrozumska, Wbrew cenzurze, [w:] Wydawnictwa podziemne w powojennym Krakowie. Materialy sesji naukowej odbytej 26 czerwca 1992 roku, Kraków 1993, s. 9-11.

4 „Bibułą w żargonie rewolucyjnym zowią każdy druk nielegalny, nieopatrzony sakramentalną formułą: »dozwolono cenzuroju«. Ilość tej bibuły z rokiem każdym wzrasta, wsiąkając coraz głębiej w warstwy ludowe, zataczając coraz szersze koła. [...] Jest więc bibuła klerykalna, patriotyczna, socjalistyczna, nawet ugodowa. Znajdziemy wśród niej utwory artystyczne wysokiej wartości, jak dzieła Wyspiańskiego lub Zycha, i lichoty patriotyczno-klerykalne; znajdziemy grube tomy badań historycznych i drobne bruszurki rozmaitych stronnictw; znajdziemy wreszcie zwyczajne książki do nabożeństwa, pisma periodyczne, odezwy, obrazki, fotografie, korespondentki i t $[\mathrm{ym}] \mathrm{p}$ [odobne] rzeczy. Wszystko to przeciska się przez granicę różnymi drogami, rozchodzi się wszędzie, gdzie ludzie umieją czytać po polsku i staje się coraz bardziej potrzeba szerokiej, stale wzrastającej warstwy ludzi”. J. Piłsudski, Pisma zbiorowe. Wydanie prac dotychczas drukiem ogloszonych, t. II, Warszawa 1937, s. 57-58.

${ }_{5}^{5}$ Ibidem, s. 57.
} 
duchową własnego społeczeństwa, jak i o rozbrojenie duchowe i demoralizację przeciwnika",

Nie można się jednak zgodzić z twierdzeniem, że przywódcy polskiego państwa podziemnego ,szybko przekonali się, że muszą mieć w ręku dwa rodzaje broni - karabin i pióro", To daleko idąca teza. Choć rzeczywiście wyjątkowo skutecznym elementem tak zwanej walki bieżącej, choć o niewojskowym charakterze, prowadzonej przez konspiracyjny Związek Walki Zbrojnej - Armię Krajową (ZWZ-AK) - stawała się właśnie działalność propagandowa. Zresztą konspiracja wojskowa musi również obejmować aspekty pozamilitarne. Co więcej, jedną z priorytetowych, a jednocześnie niezwykle skutecznych form walki bieżącej okazała się akcja wydawnicza i informacyjna ${ }^{8}$. Na zajętych przez dwóch okupantów terenach Rzeczpospolitej, jeszcze podczas działań wojennych, czyli we wrześniu 1939 r., pojawiły się pierwsze ulotki, a niedługo po nich jednokartkowe biuletyny radiowe i większe gazetki, które wzywały do walki z okupantem, zachęcały do sabotowania zarządzeń najeźdźców, wreszcie mobilizowały do czynnego udziału w konspiracji. Te początkowo samorzutne, żywiołowe i niestety bardzo amatorskie, ponieważ lekceważono przepisy konspiracji, działania $\mathrm{z}$ czasem nabierały coraz bardziej zorganizowanych $\mathrm{ram}^{9}$. Z czasem przy każdej strukturze podziemnej, wojskowej, paramilitarnej i politycznej pojawiały się specjalne zespoły prasowe, informacyjne $i$ propagandowe. Niekiedy to te zespoły dawały poczatek rozbudowywanym potem grupom podziemnym. Prowadziły wieloaspektowe działania, obejmujące nasłuch audycji radiowych, wydawanie i kolportaż prasy podziemnej.

Musiało tak być, skoro wraz z przegraną wojną kilkadziesiąt milionów obywateli Rzeczpospolitej straciło dostęp do informacji. Przestały się ukazywać wszystkie polskie periodyki, czyli sto kilkadziesiąt dzienników i ponad dwa tysiące czasopism ${ }^{10}$. Tajne biuletyny zastępowały dotychczasowe gazety i słuchanie radia. Od września 1939 r. przez pięć lat polska prasa, a w zasadzie każda forma informacji żyły tylko w podziemiu oraz na emigracji. Legalnie mogła ukazywać się tylko tak zwana prasa ,gadzinowa” (,szmatława”), będąca na usługach okupanta; która pod koniec wojny liczyła około 50 tytułów ${ }^{11}$.

Sytuację w tym zakresie przybliżał Ogólny raport polityczno-gospodarczy, który generał Michał Karaszewicz-Tokarzewski (ps. Torwid) przesłał w styczniu 1940 r. do Paryża. Dowódca Główny Służby Zwycięstwu Polski (SZP) informował: „Prasa polska nie istnieje zupełnie. Wielu dziennikarzy jest więzionych. Na terenie Gen[eralnego] Gubernatorstwa wydawane są dwa pisma codzienne, gadzinowe w języku polskim. Poziom tych pism jest niezmiernie niski. Treść odrażająca. Prowadzona przez okupantów

${ }^{6}$ G. Mazur, Biuro Informacji i Propagandy SZP, ZWZ, AK 1939-1945, Warszawa 1987, s. 9.

${ }^{7}$ M. Potyczka, Bohaterstwo udokumentowane - wydawanie i kolportaż prasy konspiracyjnej w latach 1939 1945, www.wiedzaiedukacja.eu/archives/34114.

${ }^{8}$ Por. G. Ostasz, Podziemna armia. Podokręg AK Rzeszów, Rzeszów 2010, s. 171-173.

${ }^{9}$ Z. Sokół, Rzeszowska prasa konspiracyjna (1939-1945), Rzeszów 1989, s. 36-37.

${ }^{10}$ W. Pisarek, Prasa-nasz chleb powszedni, Wrocław 1978, s. 27.

${ }^{11} \mathrm{~J}$. Święch, Literatura polska w latach II wojny światowej, Warszawa 2005, s. 22-23. Już 11 października 1939 r. wydano pierwszy numer ,gadzinówki” okupacyjnej, to jest „Nowego Kuriera Warszawskiego”, który ukazywał się do końca wojny w nakładzie około 200 tysięcy egzemplarzy. Natomiast kilka dni później, czyli 27 października 1939 r. rozpoczęła się edycja „Gońca Krakowskiego”, którego każdy numer wychodził w nakładzie około 60-75 tysięcy egzemplarzy. Łączny nakład wszystkich ,gadzinówek” w 1944 r. sięgał około 700 tysięcy egzemplarzy. A. Pilch, Propaganda hitlerowska na okupowanych ziemiach Polski poludniowej, „Studia Historyczne" 1978/1, s. 85. 
akcja prasowa ma zohydzić w oczach naszego społeczeństwa przeszłość polską i zaszczepić wiarę w wyższość kulturalną i niezwyciężalność Niemiec" ${ }^{12}$.

Nic dziwnego, że w takiej sytuacji autorzy konspiracyjnej gazety „Reforma”, miesięcznika „,ideowo-politycznego” Stronnictwa Pracy, podkreślali: „Rozumiemy i chcielibyśmy, by nasi czytelnicy zdawali sobie sprawę z tego, że wszyscy jesteśmy skazani na wchłanianie w siebie trującego jadu propagandy niemieckiej. Wróg nasz prowadzi wojnę totalną, to znaczy walczy z nami na każdym terenie, a nie tylko z bronią w ręku na froncie. Jedną z naczelnych broni uderzeniowych wroga jest propaganda, która podaje do publicznej wiadomości wyłącznie i jedynie to, co celom wroga służy a równocześnie godzi w zdrowy rozsądek człowieka, ogłupiając go i mamiąc"13. Na łamach tajnej prasy wzywano więc do bojkotu ,gadzinówek”. Przykładem mogą być hasła z „Biuletynu Informacyjnego”, które tłustym drukiem przypominały „Wszyscy do walki z fałszami propagandy niemieckiej"14. Jednocześnie zachęcano, żeby popularyzować „hasła, poglądy, informacje” tajnej prasy ${ }^{15}$.

Doświadczenia okresu ciężkiej, okrutnej, bez mała pięcioletniej okupacji niemieckiej zaowocowały podczas tak zwanej powojennej konspiracji niepodległościowej, kiedy to prym w tajnej walce politycznej o Polskę w latach 1945-1947 wiodło Zrzeszenie „Wolność i Niezawisłość” (WiN). Tym bardziej że WiN, jako organizacja niewojskowa, zrywała z militarnymi aspektami działalności podziemnej, a nastawiała się właśnie na prace propagandową i informacyjną ${ }^{16}$.

Zdaniem Łukasza Cieplińskiego, oficera AK, w latach 1941-1945 inspektora rzeszowskiego, a potem jednego z przywódców Zrzeszenia WiN, rola propagandy była równie ważna, jak choćby praca wywiadowcza. Dlatego prowadząc działalność tajną w różnych strukturach konspiracyjnych, począwszy od ZWZ-AK, oraz na coraz wyższych szczeblach dowódczych i kierowniczych, Łukasz Ciepliński zdecydowanie podkreślał, że „należy dążyć do jak najrychlejszego uruchomienia własnego wydawnictwa”"17.

Dobra informacja i skuteczna propaganda to podstawy działalności konspiracyjnej. Zresztą takie formy tajnej pracy wymuszał terror oraz nakazy i zakazy okupacyjne, w tym zakaz druku i rozpowszechniania wszelkich publikacji czy nakaz oddania aparatów

${ }^{12}$ Armia Krajowa $w$ dokumentach 1939-1945, red. T. Pełczyński, t. I: Wrzesień 1939 - czerwiec 1941, Londyn 1970, s. 54

${ }^{13}$ E. Cytowska, Szkice z dziejów prasy pod okupacja niemiecka (1939-1945), Warszawa 1986, s. 220. Dodajmy, że propaganda okupacyjna stawała się coraz bardziej wyrafinowana i zakamuflowana. Dowodzi tego choćby inny odbiór prasy „gadzinowej” w kolejnych latach okupacji. Dwudziestego stycznia 1941 r. Franciszek Kotula odnotował dość niezwykła, znamienna opinię: „Prase niemiecka, czy to w jezzyku niemieckim, czy polskim, naprawdę warto czytać. To już nie ta prasa z zeszłego roku, najpierw propagandowa, następnie zaś zachłystująca się radością zwycięstwa i pewna zwycięskiej przyszłości. Obecnie prasa widzi, że się nieco zblamowała, ludność została rozczarowana, że ta ludność cierpi i cierpieć będzie jeszcze; poczyna pisać rozsądnie, przygotowywać społeczeństwo na cierpienia i różne rozczarowania, bolesne nawet, na ciężkie chwile itp. Poczyna informować o rzeczywistości światowej, nie zasłania jej różową bibułką. Dziś już naprawdę nie trzeba łazić, szukać wiadomości, karmić się bajkami, plotkami, a przeczytawszy, czy to „Krakauera”, czy „Gońca”, na pewno zawsze znajdzie się bardzo smakowite rodzynki”. F. Kotula, Wojenne dzienniki Rzeszowa, s. 495. Por. Z. Zaremba, Wojna i konspiracja, Londyn 1957, s. 163.

14 „Biuletyn Informacyjny”, cz. 2, Przedruk roczników 1942-1943, „Przegląd Historyczno-Wojskowy”, Warszawa 2002.

${ }^{15}$ Ibidem; M. Potyczka, op. cit.

${ }^{16}$ Por. G. Ostasz, Okręg Rzeszowski Zrzeszenia „Wolność i Niezawisłość”. Model konspiracji, struktura, dzieje, Rzeszów 2006; G. Ostasz, Wydział Propagandy Rzeszowskiego Okręgu WiN, „Zeszyty Naukowe PRz” (Ekonomia i Nauki Humanistyczne) 167/7 (1998), s. 83-93.

${ }^{17}$ G. Ostasz, Okręg Rzeszowski Zrzeszenia..., s. 409 
radiowych. Podziemna prasa miała przede wszystkim podawać prawdziwe wiadomości, dementować plotki, demaskować kłamstwa niemieckiej propagandy, zwalczać przygnębienie, pouczać i wskazywać społeczeństwu, jak ma się zachowywać w ciężkich czasach okupacji, jak postępować w obliczu aktów terroru, na przykład łapanek, wywózek na roboty do Rzeszy, zabierania kontyngentów itp. ${ }^{18}$ Aleksander Kamiński (ps. Faktor, Kamyk), redaktor „Biuletynu Informacyjnego”, sformułował główne zasady, jakimi miała kierować się konspiracyjna redakcja prasowa - miała: „Informować, a nie agitować; ludzi nie trzeba w Polsce zachęcać do oporu przeciw-niemieckiego ani do patriotyzmu; ludzie pozbawieni aparatów radiowych i polskiej prasy chcą wiedzieć, co się dzieje na świecie i w kraju; te informacje należy im podawać możliwie ściśle i wiernie. Natomiast sposób podawania informacji daje okazję, którą należy inteligentnie (ale i powściągliwie) wykorzystywać w celu propagowania pożądanych zachowań, postaw, myślenia"19.

\section{BIURO INFORMACJI I PROPAGANDY ZWIĄZKU WALKI ZBROJNEJ -} ARMII KRAJOWEJ

Biorąc pod uwage te informacje, nie było nic dziwnego w tym, że już w pierwszej fazie organizacyjnej Służby Zwycięstwu Polski utworzono Oddział PolitycznoPropagandowy ${ }^{20}$. Przydzielone mu zadania - przede wszystkim walka propagandowa $\mathrm{z}$ okupantami - były potem przekazywane dalej w swoistej sztafecie organizacyjnej konspiracji wojskowej. Mianowicie w Komendzie Głównej Związku Walki Zbrojnej (a potem w Armii Krajowej) uformowano Oddział VI, również ukierunkowany na prowadzenie działalności propagandowej i informacji politycznej. Oddział VI, dla którego zalążkiem stał się wspomniany Oddział Polityczno-Propagandowy (używano tė̇ terminu Oddział Polityczny) SZP, od wiosny 1940 r. przyjął nazwę Biuro Informacji i Propagandy (BIP). Choć - jak zauważył Grzegorz Mazur - taka jednostka nie miała odpowiednika w przedwojennej strukturze Wojska Polskiego, a sama działalność propagandowa była dla wojska „w pewnym sensie pionierska”, to jednak szybko zdobyła istotne miejsce i zaczęła odgrywać wyjątkowo ważną rolę, znacząco wpływając przede wszystkim na morale, wiarę w zwycięstwo oraz kształtując postawy, a także inspirując i prowadząc akcje wychowawcze nie tylko pośród żołnierzy podziemia, ale całego społeczeństwa. To właśnie za sprawą twardo i wyjątkowo skutecznie realizowanej tajnej propagandy udało się zintegrować żołnierzy ZWZ-AK w zwartą i silną podziemną armię ${ }^{21}$. Istotnym zadaniem BIP było również kształtowanie dyscypliny wobec zarządzeń polskich władz państwowych (działających na obczyźnie oraz ich agend w konspiracji - Delegatury $\mathrm{Rządu}^{22}$ ), a także kontrowanie propagandy okupacyjnej i prowadzenie dywersji propagandowej w szeregach nieprzyjaciela. Do ważnych obowiązków Oddziału VI należało zbieranie informacji o rozwoju sytuacji międzynarodowej (politycznej i militarnej), o zbrodniach najeźdźców w Polsce, ponadto prowadzenie niepodległościowej

\footnotetext{
${ }^{18}$ Z. Jastrzębski, Konspiracyjna publicystyka literacka 1940-1944, Kraków 1973, s. 8-9; Z. Sokół, Rzeszowska prasa... s. 52.

${ }^{19}$ G. Mazur, Biuro Informacji..., s. 58.

${ }^{20}$ J. Karasiówna, Pierwsze półrocze armii podziemnej (SZP-ZWZ), „Niepodległość” Londyn 1948/I, s. 267-268; Armia Krajowa $w$ dokumentach 1939-1945, t. I, s. 163.

${ }^{21}$ G. Mazur, Biuro Informacji..., s. 17; Idem, Biuro Informacji i Propagandy ZWZ-AK, www.polishresistanceak.org/13.

${ }^{22}$ Przyjęto pisownię Delegatura Rządu dużymi literami, co - analogicznie do Armii Krajowej - wyróżnia także rolę administracyjnego elementu Polskiego Państwa Podziemnego.
} 
propagandy, piętnowanie zdrad „honoru i godności narodowej”23. Na czele Oddziału VI stali: od października 1939 r. mjr Tadeusz Kruk-Strzelecki (ps. Dyrektor, Szczepan), od października 1940 r. płk dypl. Jan Rzepecki (ps. Prezes, Rejent), a od października 1944 r. do stycznia 1945 r., czyli do rozwiązania Armii Krajowej, kpt. Kazimierz Moczarski (ps. Borsuk, Rafał $)^{24}$.

Oddział VI miał swoje bardzo aktywne komórki terenowe. Według ustaleń Grzegorza Mazura: „Oprócz BIP-u na szczeblu Komendy Głównej ZWZ-AK istniały jego komórki na niższych szczeblach organizacyjnych, w poszczególnych okręgach oraz obwodach. Ich celami było przede wszystkim realizowanie wytycznych płynących z BIP-u KG poprzez kolportowanie jego prasy, wydawanie własnej i rozsyłanie jej w terenie, prowadzenie propagandy szeptanej i za pomocą broszur i ulotek. Łącznie ukazywało się ponad 250 tytułów prasy terenowej BIP-u. Dysponując $\mathrm{z}$ kolei swoim własnym aparatem kolportażowym komórki niższych szczebli rozprowadzały swoje wydawnictwa możliwie najszerzej. W sumie przez aparat BIP-u na wszystkich szczeblach przewinęło się kilkanaście tysięcy ludzi. Na podkreślenie zasługuje również fakt, iż w BIP-ie na różnych szczeblach pracowało bardzo wielu przedstawicieli ówczesnej inteligencji: wybitni naukowcy, adwokaci, literaci i inni" 25 .

Pracę informacyjną i propagandową prowadziły praktycznie wszystkie podziemne ugrupowania. Właściwie dla większości tajnych struktur było to główne pole działalności. Organizowano nasłuch zachodnich radiostacji, których komunikaty - spisane kolportowano potem w postaci tak zwanych „pasków”. Inspirowano „propagandę szeptaną". W końcu w coraz większych nakładach i dzięki zastosowaniu coraz lepszej techniki wydawano „bibułę". Tajna propaganda stanowiła najbardziej masową formę oporu, podtrzymującą skutecznie wiarę Polaków w zwycięstwo. Największy zasięg społeczny miała niezależna prasa. Charakter tych periodyków był bardzo zróżnicowany. Stanowiły je przede wszystkim pisma wojskowe (ZWZ-AK), Delegatury Rządu, organizacji paramilitarnych, partii i stronnictw politycznych, harcerskie, kobiece i inne. Tylko szacunkowe rejestry i katalogi obejmują około 1400 tytułów, z czego jedna czwarta była drukowana, reszta zaś powielana bądź przepisywana na maszynie. Także liczba wydanych w czasie okupacji tytułów była imponująca i wyniosła ponad 1000 książek i broszur ${ }^{26}$.

Znaczenie, a właściwie siłę podziemnej propagandy szybko spostrzegli najeźdźcy. Nic dziwnego, że tajne drukarnie i podziemne czasopisma, bibuła były szczególnie pilnie tropione przez okupacyjne wojska i policję. Osoby zatrzymane podczas wydawania bądź kolportowania niecenzurowanego słowa skazywano na śmierć lub wysyłano do obozów koncentracyjnych. Jak zapisała Bożena Wyrozumska: „obieg wolnego słowa w tych czasach nienawiści i pogardy był znaczony krwią"27.

\footnotetext{
${ }^{23}$ Armia Krajowa w dokumentach 1939-1945, t. I, s. 35-36. Por. G. Mazur, Biuro Informacji.... s. 25-27; A. Skarżyński, Niektóre aspekty działalności BIP-u Komendy Głównej AK, „Wojskowy Przegląd Historyczny” $1961 / 3$.

${ }^{24}$ G. Mazur, Biuro Informacji i Propagandy ZWZ-AK; M. Ney-Krwawicz, Komenda Główna Armii Krajowej 1939-1945, Warszawa 1990, s. 179-180, 450-451.

${ }^{25}$ G. Mazur, Biuro Informacji...

${ }^{26}$ Centralny katalog polskiej prasy konspiracyjnej 1939-1945, oprac. L. Dobroszycki przy współudziale W. Kiedrzyńskiej pod kierunkiem naukowym S. Płoskiego, Warszawa 1962; W. Chojnacki, Bibliografia zwartych druków konspiracyjnych wydanych pod okupacja hitlerowska w latach 1939-1945, Warszawa 1970.

${ }^{27}$ B. Wyrozumska, op. cit., s. 11 .
} 
Dość szybko nastąpiło też uzgodnienie zasad współpracy w zakresie akcji propagandowych pomiędzy głównymi strukturami podziemia polskiego. Do Politycznego Komitetu Porozumiewawczego, swoistej platformy politycznej Polskiego Państwa Podziemnego, 26 lutego 1940 r. w charakterze sekretarza wszedł wspomniany już mjr Tadeusz Kruk-Strzelecki, szef Oddziału VI Komendy Głównej SZP-ZWZ. Wraz z nim w Politycznym Komitecie Porozumiewawczym znalazła się część Oddziału PolitycznoPropagandowego SZP-ZWZ ${ }^{28}$.

\section{DEPARTAMENT INFORMACJI I PRASY DELEGATURY RZĄDU}

Pierwszego marca 1941 r. Główny Delegat Rządu Cyryl Ratajski (ps. Wartski, Wrzos) powołał Departament Informacji i Prasy Delegatury Rządu na Kraj. Stanowisko dyrektora tego departamentu objął Stanisław Kauzik (ps. Dołęga, Modrzewski), przed wojną sekretarz Komitetu Ekonomicznego Rady Ministrów, szef Biura Prezydialnego Ministerstwa Skarbu, dyrektor Polskiego Związku Wydawców Dzienników i Czasopism, redaktor naczelny miesięcznika „Prasa”29. Podczas kampanii wrześniowej 1939 r. Stanisław Kauzik pełnił obowiązki szefa Biura Prasowego Komisarza Cywilnego Obrony Warszawy, to jest Stefana Starzyńskiego. Od końca września 1939 r. współorganizował już Tajne Biuro Pracy Społecznej, którego zadaniem była obsługa informacyjna głównych ośrodków podziemia i walka $\mathrm{z}$ nasilającą się $\mathrm{i}$ wyjątkowo agresywną propagandą niemiecką. Zastępcą dyrektora Kauzika był Tadeusz Kobylański (ps. Tadeusz Kolski, Wiktor); wcześniej zastępca szefa BIP KG ZWZ. Spora część personelu Departamentu Informacji i Propagandy wywodziła się właśnie z szeregów Tajnego Biura Pracy Społecznej ${ }^{30}$.

Do obowiązków Departamentu Informacji i Propagandy (kryptonim „Iskra”, „,600/PP”) należało: kierowanie propagandą „cywilną” w kraju, wydawanie prasy delegatury rządu, informowanie społeczeństwa o poczynaniach Rządu RP i jego krajowych pełnomocników, przygotowywanie dyrektywy dotyczące zachowania wobec okupantów i ich zarządzeń, zbieranie informacji ze wszystkich dziedzin życia okupowanej Polski i przesyłać raz na kwartał sprawozdania do Londynu. Sprawozdania obejmowały politykę władz niemieckich i sowieckich, ich administrację na okupowanych terenach, sytuację gospodarczą i społeczną, stan oświaty i kultury, postawy polityczne społeczeństwa. Od 1 sierpnia 1942 r. departament uruchomił sekcję radiową Emanuela Rudnickiego (ps. Konopka).

Do koordynacji pracy BIP Komendy Głównej ZWZ, Departamentu Informacji i Prasy Delegatury Rządu gen. Rowecki i delegat Ratajski powołali tak zwaną Radę Programową. Ze strony konspiracyjnego wojska weszli do niej: płk Jan Rzepecki, mjr Tadeusz Wardejn-Zagórski, po nim ppor. Bohdan Sałaciński i Witold Giełżyński. Delegaturę Rządu reprezentowali natomiast: Kauzik, Tadeusz Kobylański, a od aresztowania

\footnotetext{
${ }^{28}$ Armia Krajowa $w$ dokumentach 1939-1945, t. I, s. 166; Polskie Sity Zbrojne w drugiej wojnie światowej, t. III: Armia Krajowa, Londyn 1950, s. 276; G. Mazur, Biuro Informacji... s. 26, 38.

${ }^{29}$ Stanisław Kauzik vel Stanisław Dołęga-Modrzewski (1891-1959) był też, jako prawnik, członkiem delegacji polskiej na konferencję pokojową w Rydze w $1921 \mathrm{r}$.

${ }^{30}$ S. Dołęga-Modrzewski, Polskie Państwo Podziemne, Londyn 1959, s. 14-15. Por. G. Ostasz, Krakowska Okręgowa Delegatura Rządu na Kraj 1941-1945, Rzeszów 1996.
} 
Kobylańskiego w lutym 1943 r. Zbigniew Kunicki (ps. Telatycki), kierownik „wydziału prasowego" Departamentu Informacji i Prasy ${ }^{31}$.

Wydziały informacji i prasy przy okręgowych delegaturach rządu miały wyjątkowo uprzywilejowaną pozycję. Dysponowały budżetem niezależnym od delegatur okręgowych. Tworzyły własne grupy wywiadowcze ${ }^{32}$.

Z punktu widzenia Polskiego Państwa Podziemnego ważną rolę odgrywała sekcja specjalna Departamentu Informacji i Prasy; kierował nią Zbigniew Kunicki. Zajmowała się gromadzeniem materiałów i redagowaniem sprawozdań, które z początku przesyłała raz na kwartał, a od końca 1943 r. w każdym miesiącu - przez Departament Spraw Wewnętrznych - do centrali londyńskiej. Dlatego każdy okręg delegatury rządu raz w miesiącu przedkładał odpowiednie relacje $\mathrm{e}^{33}$.

$$
* * *
$$

Próbując podsumować znaczenie polskiej podziemnej propagandy okresu II wojny światowej, trzeba stwierdzić, że było ono niewątpliwie ważne i chociaż jedynie symbolicznie, ale jednak konsolidowało - w imieniu konspiracyjnych władz wojskowych - opór społeczeństwa polskiego wobec okupantów. Wpływało, a przynajmniej starało się wpływać, na postawy moralne. Tajna prasa funkcjonowała nieprzerwanie mimo warunków wojennych i okupacyjnych, budząc szacunek u Polaków, u Niemców zaś zrozumiały niepokój. Każdy dobrze przemyślany i oryginalnie dopracowany edytorsko numer konspiracyjnej gazetki stanowił - postrzeganą przez społeczeństwo - reprezentację wolnej Rzeczypospolitej oraz niezależnej informacji.

Z kolei nie sposób dzisiaj dokładnie ustalić - ponad wszelką watpliwość - jaki był rzeczywisty wpływ i zasięg oddziaływania wojskowej i cywilnej „bibuły” na świadomość i postawy Polaków w warunkach okupacji. Trudno nawet dokonać szacunkowych analiz roli i wpływu podziemnej prasy oraz jej odbioru przez poszczególne grupy społeczeństwa polskiego.

\section{LITERATURA}

[1] Armia Krajowa w dokumentach 1939-1945, red. Pełczyński T., t. I: Wrzesień 1939 - czerwiec 1941, Londyn 1970.

[2] „Biuletyn Informacyjny”, cz. 2, Przedruk roczników 1942-1943, „Przegląd

Historyczno-Wojskowy", Warszawa 2002.

[3] Centralny katalog polskiej prasy konspiracyjnej 1939-1945, oprac. Dobroszycki . L., przy współudziale W. Kiedrzyńskiej pod kierunkiem naukowym Płoskiego S., Warszawa 1962.

[4] Chojnacki W., Bibliografia zwartych druków konspiracyjnych wydanych pod okupacja hitlerowska w latach 1939-1945, Warszawa 1970.

[5] Cytowska E., Szkice z dziejów prasy pod okupacja niemiecka (1939-1945), Warszawa 1986.

\footnotetext{
${ }^{31}$ S. Dołęga-Modrzewski, op. cit., s. 71-72; G. Mazur, Biuro Informacji..., s. 39-40; G. Ostasz, Krakowska Okręgowa Delegatura..., s. 125. Zob. też AAN, 202/I-52, t. I: „Trojanowski” do „Grabowieckiego”, 28 kwietnia 1943 roku.

${ }^{32}$ G. Ostasz, Krakowska Okregowa Delegatura ... s. 125.

33 Dyrektor Departamentu Informacji i Prasy, Kauzik, podaje (op. cit., s. 83), że komplet sprawozdań przesłanych do Londynu obejmował 6 tomów, po 6000 stron każdy.
} 
[6] Dołęga-Modrzewski S., Polskie Państwo Podziemne, Londyn 1959.

[7] Jastrzębski Z., Konspiracyjna publicystyka literacka 1940-1944, Kraków 1973.

[8] Karasiówna J., Pierwsze pótrocze armii podziemnej (SZP-ZWZ), „Niepodległość” Londyn 1948/I.

[9] Kieniewicz S., Powstanie styczniowe, Warszawa 1972.

[10] Mazur G., Biuro Informacji i Propagandy SZP, ZWZ, AK 1939-1945, Warszawa 1987.

[11] Mazur G., Biuro Informacji i Propagandy ZWZ-AK, www.polishresistanceak.org/13.

[12] Ney-Krwawicz M., Komenda Gtówna Armii Krajowej 1939-1945, Warszawa 1990.

[13] Ostasz G., Krakowska Okręgowa Delegatura Rzadu na Kraj 1941-1945, Rzeszów 1996.

[14] Ostasz G., Okręg Rzeszowski Zrzeszenia ,,Wolność i Niezawisłość”. Model konspiracji, struktura, dzieje, Rzeszów 2006.

[15] Ostasz G., Podziemna armia. Podokręg AK Rzeszów, Rzeszów 2010.

[16] Ostasz G., Wydziat Propagandy Rzeszowskiego Okręgu WiN, „Zeszyty Naukowe PRz" (Ekonomia i Nauki Humanistyczne) 167/7 (1998), s. 83-93.

[17] Pilch A., Propaganda hitlerowska na okupowanych ziemiach Polski potudniowej, „Studia Historyczne” 1978/1.

[18] Piłsudski J., Pisma zbiorowe. Wydanie prac dotychczas drukiem ogłoszonych, t. II, Warszawa 1937.

[19] Pisarek W., Prasa-nasz chleb powszedni, Wrocław 1978.

[20] Polskie Sity Zbrojne w drugiej wojnie światowej, t. III: Armia Krajowa, Londyn

1950.

[21] Potyczka M., Bohaterstwo udokumentowane - wydawanie i kolportaż prasy konspiracyjnej w latach 1939-1945, www.wiedzaiedukacja.eu/archives/34114.

[21] Skarżyński A., Niektóre aspekty działalności BIP-u Komendy Głównej AK, „Wojskowy Przegląd Historyczny” 1961/3.

[22] Sokół Z., Rzeszowska prasa konspiracyjna (1939-1945), Rzeszów 1989.

[23] Święch J., Literatura polska w latach II wojny światowej, Warszawa 2005.

[24] Wyrozumska B., Wbrew cenzurze, [w:] Wydawnictwa podziemne w powojennym Krakowie. Materiały sesji naukowej odbytej 26 czerwca 1992 roku, Kraków 1993.

[25] Zaremba Z., Wojna i konspiracja, Londyn 1957.

\section{PUBLICITY AND PROPAGADA AGENDAS OF POLISH UNDERGROUND STATE}

The paper discusses the information and press releases structures in the military and civilian formations of Polish Underground State. There were shown the origin, role and objectives of covert propaganda activities. There were also presented specific organization achievements in this regard on the part of the Home Army and the Delegation of the Government of the Country.

Keywords: Polish Underground State, the Home Army.

DOI:10.7862/rz.2012.einh.14 